\title{
The availability of zinc in endosperm, whole grain and bran- enriched wheat crispbreads fed to rats on a $\mathrm{Zn}$-deficient diet
}

\author{
BY GÖRAN HALLMANS ${ }^{1,2}$, ROLF SJÖSTRÖM ${ }^{5}$, LARS WETTER ${ }^{2.3}$ \\ AND KENNETH R. WING ${ }^{4 *}$ \\ Departments of ${ }^{1}$ Nutritional Research, ${ }^{2}$ Pathology, ${ }^{3}$ Plastic Surgery and ${ }^{4}$ Oral Radiology, \\ and ${ }^{5}$ Biophysics Laboratory, University of Umeå, S-901 87 Umeå, Sweden
}

(Received 3 February 1988 - Accepted 26 January 1989)

\begin{abstract}
The hypothesis that factors such as dietary fibre and phytate in wheat bran limit the availability of $\mathrm{Zn}$ was tested in growing rats fed on low-Zn diets with different wheat crispbreads as the major source of $\mathrm{Zn}$. Six groups of six weanling male rats each were fed on 5 parts semi-synthetic $\mathrm{Zn}$-deficient diet and 1 part wheat-endosperm crispbread for 1 week. At the beginning of the second week, the crispbread in the diet of five groups was exchanged for crispbread made using one of the following wheat flours: (1) whole grain, (2) bran-enriched whole grain, (3) endosperm with $\mathrm{Zn}$ added to the whole-grain level, (4) endosperm with $\mathrm{Zn}$ added to the bran-enriched level, (5) whole grain with $\mathrm{Zn}$ added to the branenriched level. These diets were given ad lib. together with deionized water for 2.5 weeks. The relative absorption of $\mathrm{Zn}$ was lowest from the three non-supplemented diets (75-82\%). All the added $\mathrm{Zn}$ was absorbed. As appetite, body-weight increase, $\mathrm{Zn}$ absorption, $\mathrm{Zn}$ retention and the $\mathrm{Zn}$ concentrations in serum and bone differed only slightly among groups fed on diets with similar $\mathrm{Zn}$ concentrations, it is concluded that factors such as dietary fibre or phytate in wheat bran limit the availability of $\mathrm{Zn}$ in wheat crispbreads very little when all the $\mathrm{Zn}$ is needed for growth and development in rats.
\end{abstract}

Wheat bran: Zinc availability: Zinc deficiency: Rat.

Much information has been presented which appears to support the hypothesis that factors such as dietary fibre or phytate, or both, which are abundant in bran, inhibit the intestinal absorption of minerals such as zinc (Reinhold et al. 1973; Davies \& Nightingale, 1975; Sandström et al. 1980; Sandberg et al. 1982; Davies et al. 1985). The values obtained for the intestinal absorption of minerals from various foods have been referred to as their bioavailability in those foods. This implies that the mineral which was not absorbed is not available to the animal or to man. If this is the case, the binding factors in the food should limit the amount of mineral available for absorption even when the body's need for $\mathrm{Zn}$ is increased due to growth, injury, disease or greater than normal losses. In most studies reported in the literature, the experimental conditions have not been chosen or manipulated in order to increase the body's need for Zn before measuring and comparing the intestinal absorption of $\mathrm{Zn}$ from diets with high and low bran concentrations.

In an earlier study of the intestinal absorption of $\mathrm{Zn}$ in rats during the early phase of wound healing (Hallmans \& Wing, 1978), we found what we interpreted to be an increased intestinal absorption of $\mathrm{Zn}$ from wheat-endosperm crispbread compared with that in unoperated controls. In a recent investigation (Hallmans et al. 1987) we attempted to increase the need for $\mathrm{Zn}$ in rats by administering a parenteral-nutrition solution intraperitoneally, and found the intestinal absorption of $\mathrm{Zn}$ from wheat-endosperm bread to be greater than the absorption of $\mathrm{Zn}$ from the same bread in controls given physiological saline ( $9 \mathrm{~g}$ sodium chloride/l) intraperitoneally. While this indicates that more $\mathrm{Zn}$ is available than that absorbed in control animals, there was no bran in the breads and thus 
Table 1. Composition of the semi-synthetic zinc-deficient diet $(\mathrm{g} / \mathrm{kg} d r y \text { weight })^{*}$

\begin{tabular}{|c|c|}
\hline \multicolumn{2}{|l|}{ Ingredient } \\
\hline Maize starch & 375 \\
\hline Caseint & 220 \\
\hline Sucrose & 100 \\
\hline Glucose & 100 \\
\hline Soya-bean oil & 100 \\
\hline Mineral mixture, $\mathrm{Zn}$ excluded & 40 \\
\hline Celluiose & 30 \\
\hline Calcium salts $\left(\mathrm{Ca}_{2} \mathrm{SO}_{4} 18 \mathrm{mg} / \mathrm{g}, \mathrm{CaCO}_{3} 7 \mathrm{mg} / \mathrm{g}\right)$ & 25 \\
\hline Vitamin mixture (with maize starch) & 10 \\
\hline
\end{tabular}

* $2 \cdot 0 \mu \mathrm{g} \mathrm{Zn} / \mathrm{g}$ dry weight, $14.2 \mathrm{mg} \mathrm{Ca} / \mathrm{g}$ dry weight (by atomic absorption spectrophotometry).

$\uparrow$ Washed twice with EDTA.

dietary fibre and phytate concentrations can be assumed to have been low. Moreover, as the animals were fed on bread and deionized water only, a diet few humans would choose freely, this is a less than ideal experimental model.

In the present study, the hypothesis that factors such as dietary fibre and phytate in wheat bran limit the amount of $\mathrm{Zn}$ in bran available for intestinal absorption was tested in an experimental model in which the need for $\mathrm{Zn}$ was high. Growing rats were fed on diets in which the main source of $\mathrm{Zn}$ was wheat crispbread and the $\mathrm{Zn}$ concentrations were at or below the rats' requirements for growth and development. The amounts of bran and $\mathrm{Zn}$ in the diets differed among the experimental groups. Appetite, growth, intestinal absorption and retention of $\mathrm{Zn}$, and tissue and fluid $\mathrm{Zn}$ concentrations were determined and compared among the groups.

\section{MATERIALS AND METHODS}

\section{Experimental design}

Thirty-six male, albino rats of the Sprague-Dawley strain (Anticimex, Stockholm, Sweden) were used in this experiment. At the start they weighed 87.2 (SD 4.6) g. They were assigned by formal randomization to one of six groups of six rats each and they were housed separately in metabolism cages of acrylic resin and stainless steel. During the first week they were all fed $a d$ lib. on a diet containing 5 parts semi-synthetic Zn-deficient diet (Astra Ewos, Södertälje; Table 1) and 1 part wheat-endosperm crispbread. From the beginning of the second week until the end of the experiment $18 \mathrm{~d}$ later, the wheat-endosperm crispbread in the diets of five of the six groups was replaced with wheat crispbread with different $\mathrm{Zn}$ and bran concentrations (Table 2 and Fig. 1). Deionized water was also available ad lib.

The dough used to bake approximately $1 \cdot 1 \mathrm{~kg}$ crispbread contained $(\mathrm{g}): 960$ wheat flour (endosperm, whole grain or bran-supplemented whole grain), 68 yeast, 15 salt, 57 sucrose, 88 margarine, and $560 \mathrm{ml}$ water. The wheat-endosperm flour was composed of $70 \%$ extraction wheat and the bran-supplemented flour was composed of 3 parts whole-wheat flour and 2 parts wheat bran by weight. Zinc suiphate was added to some of the dough used in baking endosperm and whole-wheat crispbreads in order to achieve the same $\mathrm{Zn}$ concentration as that in the bran-enriched whole-wheat bread, and to some of the dough used in baking endosperm bread to achieve the $\mathrm{Zn}$ concentration in the whole-wheat crispbread. The phytic acid concentrations were measured using the method of Ellis et al. (1977) as modified by Sandberg et al. (1982). The dietary fibre concentrations were 
Table 2. The concentrations of zinc, phytic acid and dietary fibre (/g dry weight) in the six diets with different crispbreads as $\mathrm{Zn}$ sources* and the phytate: $\mathrm{Zn}$, and calcium $\times$ phytate: Zn, molar ratios

( $\mathrm{Zn}$ concentrations are presented as the means and standard deviations of ten $1 \mathrm{~g}$ samples)

\begin{tabular}{|c|c|c|c|c|c|c|}
\hline \multirow{3}{*}{$\begin{array}{l}\text { Crispbread in diet } \\
\text { as } \mathrm{Zn} \text { source }\end{array}$} & \multirow{2}{*}{\multicolumn{2}{|c|}{$\begin{array}{c}\mathrm{Zn} \\
(\mu \mathrm{g} / \mathrm{g})\end{array}$}} & \multirow{3}{*}{$\begin{array}{l}\text { Phytate } \\
(\mu \mathrm{mol} / \mathrm{g})\end{array}$} & \multicolumn{2}{|c|}{ Molar ratios } & \multirow{3}{*}{$\begin{array}{l}\text { Dietary fibre } \\
(\mathrm{mg} / \mathrm{g})\end{array}$} \\
\hline & & & & \multirow[b]{2}{*}{ Phytate: Zn } & \multirow{2}{*}{$\begin{array}{c}\text { Ca } \times \text { phytate }: \mathrm{Zn} \\
(\mathrm{mol} / \mathrm{kg})\end{array}$} & \\
\hline & Mean & $\mathrm{SD}$ & & & & \\
\hline Endosperm & 3.6 & $0 \cdot 2$ & $0 \cdot 5$ & 9 & $2 \cdot 7$ & 48 \\
\hline Whole wheat & $7 \cdot 0$ & 0.4 & $1 \cdot 7$ & 16 & $4 \cdot 7$ & 60 \\
\hline $\begin{array}{c}\text { Bran-enriched } \\
\text { whole wheat }\end{array}$ & $10 \cdot 1$ & 0.4 & $3 \cdot 3$ & 22 & $6 \cdot 4$ & 75 \\
\hline Endosperm + Zn & 6.8 & $0 \cdot 2$ & 0.5 & 5 & $1 \cdot 4$ & 48 \\
\hline Endosperm $+\mathrm{Zn}+\mathrm{Zn}$ & $9 \cdot 5$ & 0.6 & 0.5 & 4 & $1 \cdot 0$ & 48 \\
\hline Whole wheat $+\mathrm{Zn}$ & $9 \cdot 7$ & $0 \cdot 3$ & 1.7 & 11 & 3.4 & 60 \\
\hline
\end{tabular}

* For details, see Table 1 and Fig. 1.

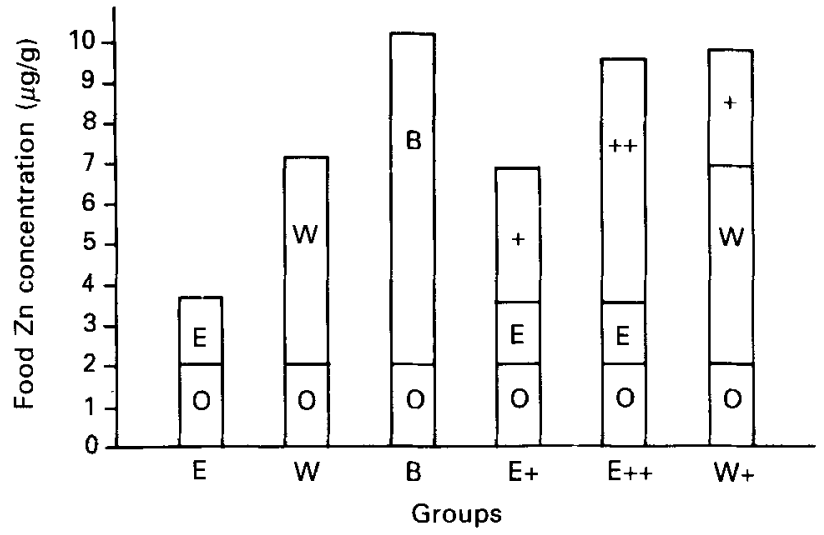

Fig. 1. The zinc concentrations and the sources of $\mathrm{Zn}$ in the composite diets given during the last $18 \mathrm{~d}$ of the experiment. $\mathrm{O}$, Zn-deficient diet; $\mathrm{E}$, wheat-endosperm; W, whole wheat; B, bran-enriched whole wheat; $\mathrm{E}+$, wheat-endosperm supplemented with $\mathrm{Zn}$ to the whole wheat level; $\mathrm{E}++$ and $\mathrm{W}+$, wheat-endosperm and whole wheat supplemented with $\mathrm{Zn}$ to the bran-enriched whole wheat level; + and ++ , supplements as zinc sulphate.

determined using the method of Asp et al. (1983). The calcium concentrations were $11.9-12.0 \mathrm{mg} / \mathrm{g}$ composite diet in all six diets.

${ }^{113} \mathrm{Sn}$-labelled microspheres (NEN-TRAC ${ }^{\mathrm{TM}}$, New England Nuclear Corp., Boston, MA, USA) were added to the dough before baking each of the six crispbreads and were used as a marker for the composite diet in the measurements of $\mathrm{Zn}$ retention. Microspheres are ionexchange resin beads coated with a polymeric resin. Those used in the present study were approximately $15 \mu \mathrm{m}$ in diameter and had a density of $1.3 \mathrm{~g} / \mathrm{ml} .{ }^{113} \mathrm{Sn}$ emits $0.392 \mathrm{MeV}$ gamma rays and has a half-life of $118 \mathrm{~d}$. The ${ }^{113} \mathrm{Sn}$ activity was $1.5 \mathrm{~Bq} /$ bead or $820 \mathrm{~Bq} / \mathrm{g}$ diet $(0.022 \mu \mathrm{Ci} / \mathrm{g}$ diet $)$. At 1 week after the change of bread in the diet, all thirty-six rats were injected subcutaneously in the nape of the neck with $5 \mu \mathrm{Ci}{ }^{65} \mathrm{Zn}$ as the chloride (Amersham International plc, Amersham, Bucks) in $0.5 \mathrm{ml}$ physiological saline ( $9 \mathrm{~g}$ sodium chloride/1). 
Each day during the $25 \mathrm{~d}$ of the experiment, the rats were weighed, the amount of food remaining in the food dispensers and cages was weighed and discarded, and newly weighed portions were put in the dispensers. During day 10 and during the last $5 \mathrm{~d}$ of the experiment, days $21-25$, the faeces were collected in weighed glass tubes for determination of the amounts of $\mathrm{Zn},{ }^{65} \mathrm{Zn}$ and ${ }^{113} \mathrm{Sn}$ excreted.

\section{Tissue sampling}

On day 25 after the start of the experiment the rats were killed by exsanguination under diethyl ether anaesthesia. Samples of blood, serum, liver, kidney, spleen and the entire femur as well as samples of the breads and composite diets were taken in weighed glass tubes. The fresh weights of all samples were recorded. The samples of faeces, blood, tissues, breads and diets were dried to constant weight at $110^{\circ}$ for $3 \mathrm{~d}$ and weighed again. They were then ashed overnight at $550^{\circ}$ and the ash was weighed. After being dissolved in $0.5 \mathrm{ml} 3$ M-hydrochloric acid and left to stand overnight, they were diluted with $2 \mathrm{ml}$ deionized water.

\section{Gamma scintillation and atomic absorption methods}

The ${ }^{65} \mathrm{Zn}$ and ${ }^{113} \mathrm{Sn}$ activities in the serum samples and the dissolved ash of the other samples were measured using a Packard Auto-Gamma Model 5330 spectrometer with a $75 \times 84 \mathrm{~mm}$ sodium iodide (T1) through-hole scintillation detector. Portions of the ${ }^{65} \mathrm{Zn}$ injection solution and the ${ }^{113} \mathrm{Sn}$-labelled diets were used as references. The background, reference and sample counting rates at the $1.119 \mathrm{MeV}{ }^{65} \mathrm{Zn}$ and the $0.392 \mathrm{MeV}{ }^{113} \mathrm{Sn}$ gamma peaks were measured and the ${ }^{65} \mathrm{Zn}$ activity was stripped from the total activity in the $0.392 \mathrm{MeV}$ peak for each sample in order to recover the ${ }^{113} \mathrm{Sn}$ activity.

The ashed samples were further diluted with $0.6 \mathrm{M}-\mathrm{HCl}$ as necessary and the serum samples were diluted tenfold with $0 \cdot 1 \mathrm{M}-\mathrm{HCl}$ for the determination of the $\mathrm{Zn}$ concentrations using a Varian Techtron Model AA-6DB atomic absorption spectrophotometer at 213.9 $\mathrm{nm}$. Known amounts of $\mathrm{Zn}$ dissolved in $0.6 \mathrm{M}-\mathrm{HCl}$ were used as references (Hallmans, 1978).

\section{Calculations}

The $\mathrm{Zn}$ retentions during days 10 and 21-25 were calculated. The amount of diet represented by the faeces is first calculated by dividing the ${ }^{113} \mathrm{Sn}$ activity/g faeces by the ${ }^{113} \mathrm{Sn}$ activity/g diet. The $\mathrm{Zn}$ excreted in the faeces is then divided by the amount of diet represented by the faeces and subtracted from the $\mathrm{Zn}$ concentration in the original diet:

$\mathrm{Zn}$ retention $(\mu \mathrm{g} / \mathrm{g}$ diet $)=\mathrm{Zn}$ in diet $(\mu \mathrm{g} / \mathrm{g}$ diet $)-\mathrm{Zn}$ in faeces $(\mu \mathrm{g} / \mathrm{g}$ diet in faeces $)$.

The $\mathrm{Zn}$ retention per $\mathrm{d}$ or per measurement period can be calculated by multiplying the retention $(\mu \mathrm{g} \mathrm{Zn} / \mathrm{g}$ diet) by the amount of diet recovered in faeces per $\mathrm{d}$ or per measurement period.

The calculation of $\mathrm{Zn}$ retention requires that the ${ }^{113} \mathrm{Sn}$ in the microspheres is not absorbed. As no measurable ${ }^{113} \mathrm{Sn}$ was detected in any organ at death after $18 \mathrm{~d}$ on the ${ }^{113}$ Sn-labelled diet, it can be assumed that the microspheres were in fact not absorbed and that no ${ }^{113} \mathrm{Sn}$ leaked from the microspheres.

The amount of $\mathrm{Zn}$ absorbed is calculated by adding to the $\mathrm{Zn}$ retention (/g diet) the amount of endogenous $\mathrm{Zn}$ excreted (/g diet) (Weigand \& Kirchgessner, 1976a). The excretion of endogenous $\mathrm{Zn}$ was calculated by dividing the ${ }^{65} \mathrm{Zn}$ activity in the daily collections of faeces by the time-corrected ${ }^{65} \mathrm{Zn}$ specific activity in serum:

$\mathrm{Zn}$ absorbed $(/ \mathrm{g}$ diet $)=\mathrm{Zn}$ retention $(/ \mathrm{g}$ diet $)+\frac{\text { faeces }\left({ }^{65} \mathrm{Zn}:{ }^{113} \mathrm{Sn}\right) \times\left({ }^{113} \mathrm{Sn} / \mathrm{g} \text { diet }\right)}{\operatorname{serum}\left({ }^{65} \mathrm{Zn}: \mathrm{Zn}\right)}$ 


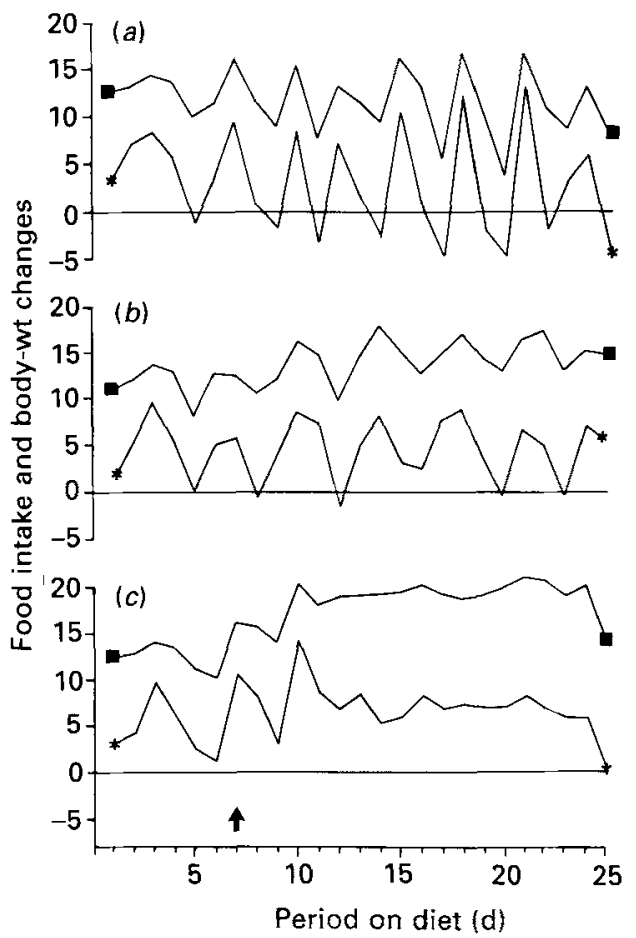

Fig. 2. Diet consumption ( $\mathrm{g} / \mathrm{d}, \mathbf{\square})$ and body-weight changes $\left(\mathrm{g} / \mathrm{d},{ }^{*}\right)$ of rats fed on a composite diet with wheat crispbread as the main source of zinc. All rats were fed on a diet with wheat-endosperm crispbread (3.6 $\mu \mathrm{g} \mathrm{Zn/g}$ diet) during the first week. During the subsequent $18 \mathrm{~d}$ they were fed on the same diet with different breads for different groups. For details of diet and breads, see Tables 1 and 2 and Fig. 1. (a) A rat from the group fed on a diet with wheat-endosperm crispbread $(3.6 \mu \mathrm{g} \mathrm{Zn} / \mathrm{g} \mathrm{diet}),(b)$ a rat from the group fed on a diet with whole wheat crispbread $(7.0 \mu \mathrm{g} \mathrm{Zn} / \mathrm{g}$ diet $),(c)$ a rat from the group fed on a diet with bran-enriched whole wheat crispbread $(10 \cdot 1 \mu \mathrm{g} \mathrm{Zn} / \mathrm{g}$ diet $) . \uparrow$, Start of the different diets.

The time-corrected ${ }^{65} \mathrm{Zn}$ specific activity in serum for a particular collection period is calculated by extrapolating the specific activity in serum at death back in time using the slope of the change in ${ }^{65} \mathrm{Zn}$ specific activity in the faeces according to the method of Weigand \& Kirchgessner $(1976 b)$. In these calculations we have assumed the time interval from the excretion of $\mathrm{Zn}$ into the intestinal lumen until its appearance in the faeces to be $12 \mathrm{~h}$.

\section{Statistics}

The means for a given variable in the six groups were tested using a one-way analysis of variance $(F)$. If a statistically significant result was obtained $(P<0.01)$, a priori contrasts of the diet groups were tested with least significant differences (LSD). Pearson productmoment correlation coefficients $(r)$ for pairs of variables were calculated and tested using Student's $t$ test (Snedecor \& Cochran, 1967). In all statistical tests we have chosen to reject the null hypothesis at the $1 \%$ level $(P<0.01)$.

\section{RESULTS}

Eating patterns. The eating patterns of all thirty-six rats were cyclical by the end of the first week on the composite Zn-deficient diet with wheat-endosperm crispbread (Fig. 2). During the second week, this cyclical pattern almost disappeared in the three groups with the 


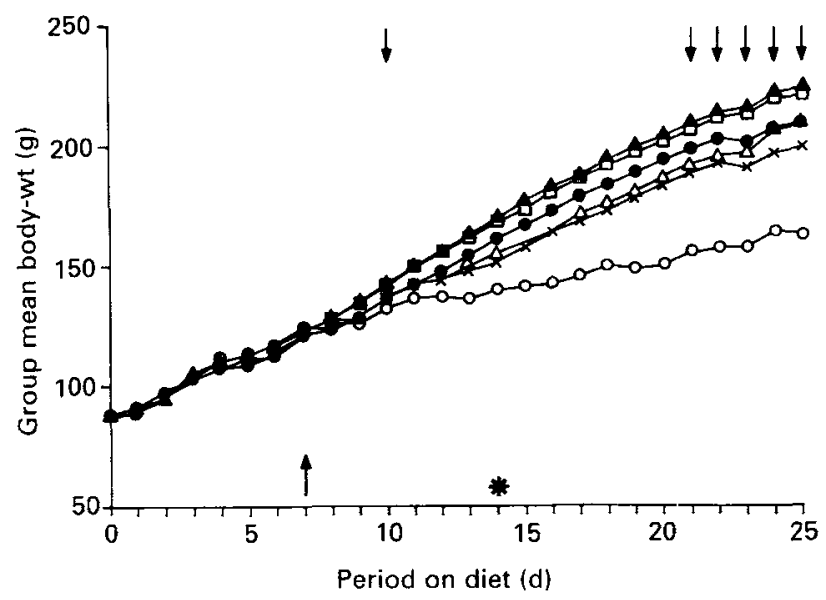

Fig. 3. Group mean daily body-weight of rats fed on a composite diet with wheat crispbread as the main source of zinc. All rats were fed on a diet with wheat-endosperm crispbread $(3.6 \mu \mathrm{g} \mathrm{Zn} / \mathrm{g}$ diet) during the first week. During the subsequent $18 \mathrm{~d}$ they were fed on the same diet with different breads for different groups. $O$, Wheatendosperm (3.6 $\mu \mathrm{g} \mathrm{Zn/g} \mathrm{diet);} \triangle$, whole wheat (7.0 $\mu \mathrm{g} \mathrm{Zn/g} \mathrm{diet);} \square$, bran-enriched whole wheat (10.1 $\mu \mathrm{g} \mathrm{Zn/g}$ diet); $X$, wheat-endosperm supplemented with $\mathrm{Zn}$ to the whole wheat level $(6.8 \mu \mathrm{g} \mathrm{Zn} / \mathrm{g}$ diet); endosperm supplemented with $\mathrm{Zn}$ to the bran-enriched whole wheat level $(9.5 \mu \mathrm{g} \mathrm{Zn} / \mathrm{g}$ diet $) ; \boldsymbol{\Delta}$, whole wheat supplemented with $\mathrm{Zn}$ to the bran-enriched whole wheat level $(9.7 \mu \mathrm{g} \mathrm{Zn} / \mathrm{g}$ diet $) . \uparrow$, Start of the different diets; * day on which ${ }^{65} \mathrm{Zn}$ was injected; $\downarrow$, days on which $\mathrm{Zn}$ retention studies were made. For details of diet and breads, see Tables 1 and 2 and Fig. 1 .

highest $\mathrm{Zn}$ concentrations in their diets (Fig. 2(c)) but continued in the three groups with less $\mathrm{Zn}$ (Fig. 2( $a$ and $b)$ ).

Food intake and body-weight gain. The cumulative food intake and the gain in bodyweight during the first week were similar in all six groups (Fig. 3). The amount of composite diet consumed and the gain in body-weight during the next $18 \mathrm{~d}$ were significantly different among groups with different dietary $\mathrm{Zn}$ concentrations (Table 3). The weight gain in individual rats was directly related to the amount of diet consumed $(r 0.95, P<0.001)$. The rats' appetites increased non-linearly with increasing $\mathrm{Zn}$ concentration in the diet but they were not affected by the amount of bran. Groups given Zn-supplemented endosperm breads had consistently lower increases in body weight than groups fed on whole wheat or bran-enriched whole wheat breads with similar $\mathrm{Zn}$ concentrations, but these differences were not significant (Table 3 ).

$\mathrm{Zn}$ absorption. The absorption of $\mathrm{Zn}$ from the six diets $(\mu \mathrm{g} \mathrm{Zn} / \mathrm{g}$ diet) was significantly different among groups with different dietary $\mathrm{Zn}$ concentrations (Table 3). The $\mathrm{Zn}$ absorption was not significanly different among groups with similar dietary $\mathrm{Zn}$ concentrations, with one exception. In the group given the bran-enriched diet, $\mathrm{Zn}$ absorption was slightly less than that in the other two groups with similar dietary $\mathrm{Zn}$ concentrations. The relative absorption of $\mathrm{Zn}$ was lowest from the three non-supplemented diets (75-82\%). The absorption of the Zn supplements was in all cases close to $100 \%$.

Endogenous $\mathrm{Zn}$ excretion and $\mathrm{Zn}$ retention. The excretion of endogenous $\mathrm{Zn}$ was most pronounced in the three groups with the highest dietary $Z n$ concentrations (Table 3). The excretion of endogenous $\mathrm{Zn}$ did not differ among groups given diets with similar $\mathrm{Zn}$ concentrations. The average $\mathrm{Zn}$ retention for days 21-25 was significantly different among groups with different dietary $\mathrm{Zn}$ concentrations (Table 3 ). The $\mathrm{Zn}$ retention in the group given the bran-enriched diet was slightly less than that in the other two groups with similar dietary $\mathrm{Zn}$ concentrations, while that in the other groups with similar $\mathrm{Zn}$ concentrations 
A

||

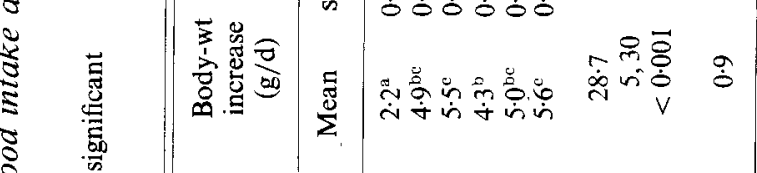

20

要

$\cong \Sigma$

ชิ

公骂

$\uparrow ะ$

त है

要

롱

งิ

궁

눙

so

过

ㅇำ

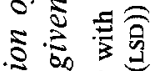

डัँ

के

今

㮍|

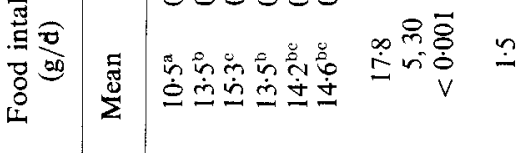

के के

密

S.

$5 \widehat{2}$

ำ

気

है

ฐ

ํำ

कृ

능

害荠

空 8

i

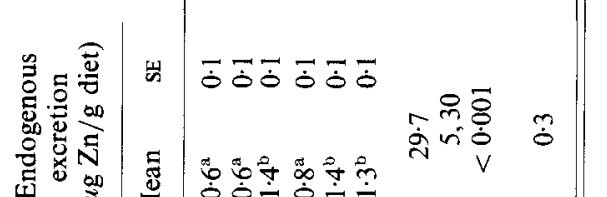

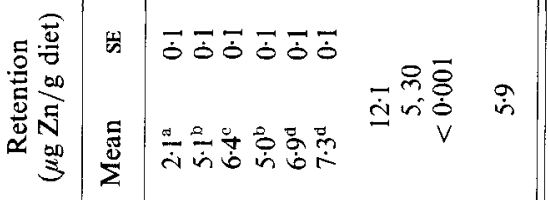

产

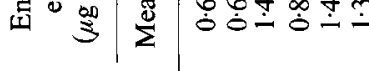

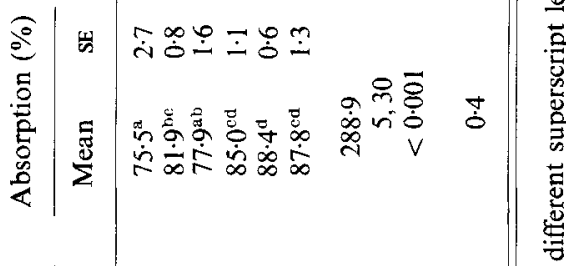

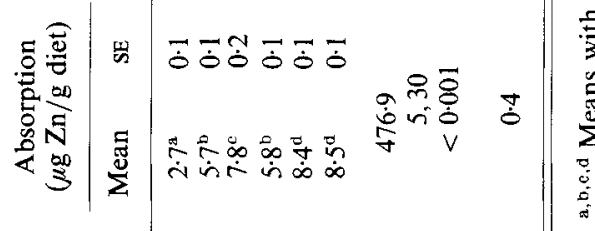

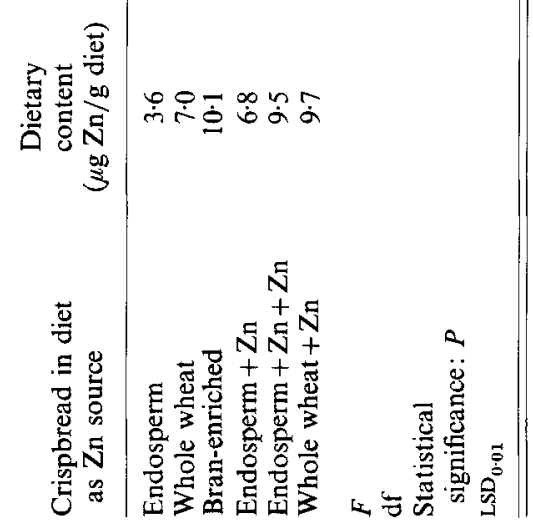


Table 4. The fresh weight zinc concentrations in serum, whole blood, liver and femur, and $\mathrm{Zn}$ on the basis of the ash weight in femur

(Means for groups of six rats with their standard errors are presented together with the results of one-way analyses of variance $(F)$ and least significant differences (LSD))

\begin{tabular}{|c|c|c|c|c|c|c|c|c|c|c|}
\hline \multirow{2}{*}{$\begin{array}{l}\text { Crispbread } \\
\text { in the diet } \\
\text { as } \mathrm{Zn} \text { source }\end{array}$} & \multicolumn{2}{|c|}{$\begin{array}{c}\text { Serum } \\
(\mu \mathrm{g} \mathrm{Zn} / \mathrm{g})\end{array}$} & \multicolumn{2}{|c|}{$\begin{array}{c}\text { Blood } \\
(\mu \mathrm{g} \mathrm{Zn} / \mathrm{g})\end{array}$} & \multicolumn{2}{|c|}{$\begin{array}{l}\text { Liver } \\
(\mu \mathrm{g} \mathrm{Zn} / \mathrm{g})\end{array}$} & \multicolumn{2}{|c|}{$\begin{array}{c}\text { Femur } \\
(\mu \mathrm{g} \mathrm{Zn/g)}\end{array}$} & \multicolumn{2}{|c|}{$\begin{array}{c}\text { Femur } \\
(\mu \mathrm{g} \mathrm{Zn/g} \text { ash) }\end{array}$} \\
\hline & Mean & $\mathrm{SE}$ & Mean & SE & Mean & $\mathrm{SE}$ & Mean & $\mathrm{SE}$ & Mean & SE \\
\hline Endosperm & $0 \cdot 63^{\mathrm{a}}$ & 0.04 & 3.67 & $0 \cdot 34$ & $30 \cdot 2$ & $1 \cdot 1$ & $34 \cdot 2^{\mathrm{a}}$ & $1 \cdot 8$ & $73 \cdot 6^{\mathrm{a}}$ & 1.9 \\
\hline Whole wheat & $0.52^{\mathrm{a}}$ & 0.03 & 3.56 & $0 \cdot 10$ & $29 \cdot 0$ & $0 \cdot 4$ & $31 \cdot 6^{\mathrm{a}}$ & $1 \cdot 3$ & $74 \cdot 9^{\mathrm{ab}}$ & $2 \cdot 3$ \\
\hline Bran-enriched & $0 \cdot 77^{\mathrm{b}}$ & 0.02 & 3.66 & $0 \cdot 17$ & $30 \cdot 8$ & $1 \cdot 0$ & $47 \cdot 0^{\mathrm{b}}$ & $2 \cdot 7$ & $101 \cdot 4^{c}$ & $2 \cdot 1$ \\
\hline Endosperm + Zn & $0.58^{a}$ & 0.02 & 3.89 & $0 \cdot 16$ & $29 \cdot 9$ & 0.8 & $37 \cdot 8^{\mathrm{ac}}$ & $2 \cdot 5$ & $82 \cdot 6^{\mathrm{b}}$ & $1 \cdot 7$ \\
\hline Endosperm $+\mathrm{Zn}+\mathrm{Zn}$ & $0.84^{b}$ & $0 \cdot 04$ & 3.96 & $0 \cdot 11$ & $29 \cdot 7$ & $0 \cdot 7$ & $45 \cdot 0^{\mathrm{bc}}$ & $1 \cdot 7$ & $100 \cdot 4^{c}$ & $1 \cdot 7$ \\
\hline Whole wheat $+\mathrm{Zn}$ & $0 \cdot 76^{\mathrm{b}}$ & 0.01 & $4 \cdot 10$ & $0 \cdot 15$ & $30-3$ & 0.7 & $49 \cdot 4^{b}$ & $2 \cdot 4$ & $98.8^{\circ}$ & $2 \cdot 3$ \\
\hline$F$ & \multicolumn{2}{|c|}{$17 \cdot 79$} & \multicolumn{2}{|c|}{1.20} & \multicolumn{2}{|c|}{$0 \cdot 56$} & \multicolumn{2}{|c|}{$11 \cdot 79$} & \multicolumn{2}{|c|}{$42 \cdot 50$} \\
\hline$d f$ & \multicolumn{2}{|c|}{5,30} & \multicolumn{2}{|c|}{5,30} & \multicolumn{2}{|c|}{5,30} & \multicolumn{2}{|c|}{5,30} & \multicolumn{2}{|c|}{5,30} \\
\hline $\begin{array}{l}\text { Statistical } \\
\text { significance: } P\end{array}$ & \multicolumn{2}{|c|}{$<0.001$} & \multicolumn{2}{|c|}{$>0.05$} & \multicolumn{2}{|c|}{$>0.05$} & \multicolumn{2}{|c|}{$<0.001$} & \multicolumn{2}{|c|}{$<0.001$} \\
\hline $\mathrm{LSD}_{0 \cdot 01}$ & \multicolumn{2}{|c|}{0.12} & \multicolumn{2}{|c|}{-} & \multicolumn{2}{|c|}{ - } & \multicolumn{2}{|l|}{$8 \cdot 3$} & \multicolumn{2}{|l|}{$7 \cdot 8$} \\
\hline
\end{tabular}

a, b, c Means with different superscript letters are significantly different $(P<0 \cdot 01)$.

did not differ significantly from each other. The $\mathrm{Zn}$ retention was directly related to the $\mathrm{Zn}$ concentration in the diet and was only $0.6-1.4 \mu \mathrm{g} \mathrm{Zn} / \mathrm{g}$ diet less than the absorption. The relations among the retentions of $\mathrm{Zn}$ in the six groups on day 10 were nearly the same as those for days $21-25$. The variance $\left(\mathrm{SD}^{2}\right)$ in the $\mathrm{Zn}$ concentrations in each diet (Table 2 ) was large enough to influence the variance of the $\mathrm{Zn}$ retention $\left(\mathrm{SI}^{2}=n \times \mathrm{SE}^{2} ; n 6\right)$ in that group (Table 3).

Serum and tissue $\mathrm{Zn}$. The serum and femur $\mathrm{Zn}$ concentrations differed significantly among the six groups but not among groups with similar $\mathrm{Zn}$ concentrations in their diets (Table 4). The concentrations were highest in the three groups on diets with the highest $\mathrm{Zn}$ contents. The $\mathrm{Zn}$ concentrations of blood and liver were similar for all six groups.

\section{DISCUSSION}

The minimum requirement for $\mathrm{Zn}$ for optimal growth in young rats is $12.5-13 \mu \mathrm{g} \mathrm{Zn} / \mathrm{g}$ food (Williams \& Mills, 1970). The Zn concentrations in the composite diets fed to the rats in the present study were all below that level. The gain in body-weight in each of the thirtysix rats was directly related to the amount of food consumed regardless of the dietary $\mathrm{Zn}$ concentration. The lower cumulative consumption of food in the groups with lower $\mathrm{Zn}$ concentrations in their diets was not due to an overall reduction in appetite but due to recurrent periods of low food intake (Figs. 2 and 3). This cyclical eating behaviour in rats fed on diets low in $\mathrm{Zn}$ has been observed as a symptom of Zn deficiency in earlier studies (Chesters \& Quarterman, 1970; Williams \& Mills, 1970; Davies \& Nightingale, 1975) and it may be the result of $\mathrm{Zn}$ deficiency limiting the utilization of amino acids in protein synthesis and causing the amino acids to be used as a source of energy. The rats' appetites will then be reduced until catabolic processes release $\mathbf{Z n}$ which can be used in protein synthesis. The incorporation of amino acids into protein will increase the appetite and reduce the amount of $\mathrm{Zn}$ available, thus completing the cycle.

Davies et al. (1985) have demonstrated a negative linear relation between the gain in 
body-weight and the $\mathrm{Ca} \times$ phytate: $\mathrm{Zn}$ molar ratio in the diet at values above $3.5 \mathrm{~mol} / \mathrm{kg}$ ( $\mathrm{Zn}>11 \mu \mathrm{g} / \mathrm{g}$ diet). Davies et al. (1977), Davies \& Olpin (1979) and Morris \& Ellis (1980) demonstrated markedly reduced growth rates in rats fed on diets in which the $\mathrm{Ca} \times$ phytate: $\mathrm{Zn}$ molar ratios were extremely high, i.e. 8 or more (phytate: $\mathrm{Zn}>40, \mathrm{Ca}$ concentration $>7.5 \mathrm{mg} / \mathrm{g}$ ). For groups of rats fed on diets with more moderate molar ratios, i.e. about 5 (Morris \& Ellis, 1980; Davies et al. 1985), the growth rate was reduced only marginally. In the present study, the molar ratios were between 1.0 and 6.4 and there were no demonstrable differences in body-weight in groups given diets with similar $\mathrm{Zn}$ concentrations. The $\mathrm{Zn}$ concentrations in the bran-enriched diet and in the endosperm and whole wheat diets supplemented with $\mathrm{Zn}$ to the bran-enriched level (9.5-10.1 $\mu \mathrm{g} \mathrm{Zn} / \mathrm{g})$ were lower than in all but one experimental group in the studies cited previously and were low enough to limit growth slightly, even in the group fed on a diet with a molar ratio of 1.0 . It would appear that, at these $\mathrm{Zn}$ concentrations, the increase in molar ratio from 1.0 to 6.4 has no further effect on weight gain.

The absorption and retention of $\mathrm{Zn}$ and the serum, blood and femur $\mathrm{Zn}$ concentrations were also used as measures of the availability of $\mathrm{Zn}$ from the different crispbreads. The absorption and retention of $\mathrm{Zn}(\mu \mathrm{g} / \mathrm{g}$ diet) were slightly but significantly reduced by the addition of bran to the diet. However, as the rats ate more of the bran-enriched diet than either the endosperm or the whole grain diets supplemented with $\mathrm{Zn}$ to the bran-enriched level, the daily $\mathrm{Zn}$ intake, the average daily weight gain and the $\mathrm{Zn}$ concentrations in the serum, blood, liver and femur were nearly equal in these three groups. As unrefined foodstuffs such as whole-wheat flour and wheat bran generally have high concentrations of minerals such as $\mathrm{Zn}$ and, at the same time, have less energy, and in some cases protein, than their refined counterparts, it might be more appropriate to relate $\mathrm{Zn}$ absorption to the amount of energy or protein consumed than to express it relative to the amount of $\mathrm{Zn}$ or diet consumed.

Earlier studies have demonstrated considerable inhibition of $\mathrm{Zn}$ absorption when $10 \mathrm{mg}$ phytate/g was added to a basal diet containing $15 \mu \mathrm{g} \mathrm{Zn} / \mathrm{g}$ and $13 \mathrm{mg} \mathrm{Ca} / \mathrm{g}$ (phytate: $\mathrm{Zn}=66 ; \mathrm{Ca} \times$ phytate $: \mathrm{Zn}=22$ ). (Davies \& Nightingale, 1975) or when $20 \mathrm{mg}$ phytate $/ \mathrm{g}$ was added to a diet containing $33 \mu \mathrm{g} \mathrm{Zn/g}$ diet (phytate: $\mathrm{Zn}=60$ ) (House et al. 1982). While such experiments show the ability of phytate to impair $\mathrm{Zn}$ absorption, the experimental conditions were non-physiological due to the extreme concentrations of phytate and the fact that phytate was added in purified form. The addition of 50,100 or $150 \mathrm{mg}$ bran/g to a basal diet containing $54 \mu \mathrm{g} \mathrm{Zn} / \mathrm{g}$ and $8 \mathrm{mg} \mathrm{Ca} / \mathrm{g}$ (phytate: $\mathrm{Zn}<10$; $\mathrm{Ca} \times$ phytate: $\mathbf{Z n}<2$ ) left the relative $\mathrm{Zn}$ retention unchanged (Bagheri \& Gueguen, 1981). In the present study a diet containing $10 \mu \mathrm{g} \mathrm{Zn} / \mathrm{g}$ and $12 \mathrm{mg} \mathrm{Ca} / \mathrm{g}$ prepared by adding approximately $75 \mathrm{mg}$ bran $/ \mathrm{g}$ in the form of bran-enriched crispbread to a basal diet (phytate: $\mathrm{Zn}=22 ; \mathrm{Ca} \times$ phytate $: \mathrm{Zn}=6.4$ ) caused small but significant decreases in relative $\mathrm{Zn}$ absorption from 88 to $78 \%$ and relative $\mathrm{Zn}$ retention from 75 to $63 \%$. Thus, in diets in which the phytate: $\mathrm{Zn}$ molar ratio is close to that of high-fibre diets consumed by humans and the phytate is in its natural form, there is little or no demonstrable impairment of $\mathrm{Zn}$ absorption in rats. However, diets with bran with phytate: $\mathrm{Zn}$ molar ratios of less than 10 have been shown to reduce $\mathrm{Zn}$ absorption from composite meals in humans (for example, see Sandström et al. 1980). The differences between the results of studies on rats and humans may be the result of species differences but they may also be the result of differences in the experimental conditions and the choice of measurement to represent availability.

In the present study the three groups given diets in which the naturally occurring $\mathrm{Zn}$ in the wheat flour used to bake the breads was the source of $\mathrm{Zn}$ showed lower relative absorption of $\mathrm{Zn}$ than the three groups given diets supplemented with $\mathrm{ZnSO}_{4}$ due to the fact that all the supplemented $\mathrm{Zn}$ was absorbed. The absorption of $100 \%$ of the 
supplemented $\mathrm{Zn}$ reflects the body's pressing need for $\mathrm{Zn}$ in the rats in the present study. At dietary $\mathrm{Zn}$ levels above the requirement level, the absorption of supplemented $\mathrm{Zn}$ is incompletely regulated as part of the body's Zn homeostasis (Becker \& Hoekstra, 1971; Evans et al. 1973; Weigand \& Kirchgessner, 1978). If the mineral-binding factors in bran function as ion exchangers, they may act as a mineral reserve when the body's need is near the mineral content of the diet but offer resistance to the free absorption of mineral when the mineral concentration exceeds the body's need. In this way, these factors could complement the body's homeostatic regulation of $\mathrm{Zn}$. If this is the case, it may not be appropriate to use the absorption of $\mathrm{Zn}$ as a measure of its availability when the $\mathrm{Zn}$ concentration in the food clearly exceeds the body's needs.

The combined results of the present study (weight gain, $\mathrm{Zn}$ absorption, $\mathrm{Zn}$ retention, and tissue and fluid $\mathrm{Zn}$ concentrations) demonstrate that mineral-binding factors such as dietary fibre and phytate in wheat bran do not to any appreciable extent limit the availability of $\mathrm{Zn}$ to growing rats from diets in which the main source of $\mathrm{Zn}$ is crispbread if the $\mathrm{Zn}$ in these diets is below the minimum requirements for growth and development. The dietary fibre and phytate contents of the bran-enriched diet used in the present study were comparable to those in high-fibre diets consumed by humans. The concentration of bran in the bran-enriched bread was as high as baking techniques allowed and the amount of bread in the diet was high for most diets for humans. While it is not possible to use these results to represent the relative availability to humans of $\mathrm{Zn}$ from different crispbreads in their diets, it is very likely that differences in the availability to humans of $\mathrm{Zn}$ between diets with and without wheat bran will be very small if the dietary $\mathrm{Zn}$ content is near or below the body's needs. This and the ability of the body to adjust its growth and rnetabolism to the availability of $\mathrm{Zn}$ in the diet may be the reasons for the rarity of manifest $\mathrm{Zn}$ deficiency in the Western population, despite the fact that $\mathrm{Zn}$ intake is often below recommended levels and $\mathrm{Zn}$ absorption has been shown to be relatively low and easily impaired by many factors in the diet.

This study was supported by the National Swedish Board for Technical Development, Swedish Council for Planning and Coordination of Research and Swedish Medical Research Council. The authors wish to thank Ms A.-M. Ảhren, U.-S. Kågström and I. Sjöström for skilful technical assistance.

\section{REFERENCES}

Asp, N.-G., Johansson, C. G., Hallmer, H. \& Siljeström, M. (1983). Rapid enzymatic assay of insoluble and soluble dietary fiber. Journal of Agricultural and Food Chemistry 31, 476-482.

Bagheri, S. M. \& Gueguen, L. (1981). Influence of wheat bran diets containing unequal amounts of calcium, magnesium, phosphorus and zinc upon the absorption of these minerals in rats. Nutrition Reports International 24, 47-56.

Becker, W. M. \& Hoekstra, W. G. (1971). The intestinal absorption of zinc. In Trace Elements and Radionuclides. Intestinal Absorption of Metal Ions, pp. 229-256 [S. C. Skornya and D. Waldron-Edward, editors]. Oxford: Pergamon Press.

Chesters, J. K. \& Quarterman, J. (1970). Effects of zinc deficiency on food intake and feeding patterns of rats British Journal of Nutrition 24, 1061-1069.

Davies, N. T., Carswell, A. J. P. \& Mills, C. F. (1985). The effect of variation in dietary calcium intake on the phytate-zinc interaction in rats. In Trace Elements in Man and Animals-TEMA 5 pp. $456-457$ [C. F. Mills, I. Bremner and J. K. Chesters, editors]. Aberdeen: Commonwealth Agricultural Bureaux.

Davies, N. T., Hristic, V.\& Flett, A. A. (1977). Phytate rather than fibre in bran as the major determinant of zinc availability to rats. Nutrition Reports International 15, 207-214.

Davies, N. T. \& Nightingale, R. (1975). The effects of phytate on the intestinal absorption and secretion of zinc, and whole-body retention of $\mathrm{Zn}$, copper, iron and manganese in rats. British Journal of Nutrition 34, $243-258$.

Davies, N. T. \& Olpin, S. E. (1979). Studies on the phytate: zinc molar contents in diets as a determinant of $\mathrm{Zn}$ availability to young rats. British Journal of Nutrition 41, 590603. 
Ellis, R., Morris, E. R. \& Philpot, C. (1977). Quantitative determination of phytate in the presence of high inorganic phosphate. Analytical Biochemistry 2, 536-539.

Evans, G. W., Grace, C. I. \& Hahn, C. (1973). Homeostatic regulation of zinc absorption in the rat. Proceedings of the Society for Experimental Biology and Medicine 143, 723-725.

Hallmans, G. (1978). Absorption of topically applied zinc and changes in zinc metabolism during wound healing. Acta Dermato-Venereologica 58, Suppl. 80.

Hallmans G., Nilsson, U., Sjöström, R., Wetter, L. \& Wing, K. (1987). The importance of the body's need for zinc in determining $\mathrm{Zn}$ availability in food: a principle demonstrated in the rat. British Journal of Nutrition $\mathbf{5 8}$, $59-64$.

Hallmans, G. \& Wing, K. (1978). Effects of early wound healing and wound treatment with zinc tape on intestinal absorption and distribution of zinc in rats. Acta Chirurgica Scandinavica 144, 431-439.

House, W. A., Welch, R. M. \& van Campen, D. R. (1982). Effect of phytic acid on the absorption, distribution and exogenous excretion of zinc in rats. Journal of Nutrition 112, 941-953.

Morris, R. M. \& Ellis, R. (1980). Bioavailability to rats of iron and zinc in wheat bran: response to low-phytate bran and effect of the phytate/zinc molar ratio. Journal of Nutrition 110, 2000-2010.

Reinhold, J. G., Nasr, K., Lahimgarzadeh, A.\& Hedayati, H. (1973). Effects of purified phytate and phytate-rich bread upon metabolism of zinc, calcium, phosphorus and nitrogen in man. Lancet 1, 283-288.

Sandberg, A.-S., Hasselblad, C., Hasselblad, K. \& Hulten, L. (1982). The effect of wheat bran on the absorption of minerals in the small intestine. British Journal of Nutrition 48, 185-191.

Sandström, B., Arvidsson, B., Cederblad, A. \& Björn-Rasmussen, E. (1980). Zinc absorption from composite meals. I. The significance of wheat extraction rate, zinc, calcium, and protein content in meals based on bread. American Journal of Clinical Nutrition 33, 739-745.

Snedecor, G. \& Cochran, W. (1967). Statistical Methods, 6th ed. Ames, Iowa: Iowa State University Press.

Weigand, E. \& Kirchgessner, M. (1976a). Radioisotope dilution technique for determination of zinc absorption in vivo. Nutrition and Metabolism 20, 307-313.

Weigand, E. \& Kirchgessner, M. (1976b). ${ }^{65} \mathrm{Zn}$-labelled tissue zinc for determination of endogenous fecal excretion in growing rats. Nutrition and Metabolism 20, 314-320.

Weigand, E. \& Kirchgessner, M. (1978). Homeostatic adjustments in zinc digestion to widely varying dietary zinc intake. Nutrition and Metabolism 22, 101-112.

Williams, R. B. \& Mills, C. F. (1970). The experimental production of zinc deficiency in the rat. British Journal of Nutrition 24, 989-1003. 